\title{
Effectiveness of Nanomaterial in the Roof of the Building to Achieve Energy Conservation for Indoor Environment of the Building
}

\author{
Duaa Faal * \\ MSc. Student \\ University of Baghdad \\ Baghdad-Iraq \\ Eng.duaan@yahoo.com
}

\author{
Dr. Ghada M.Ismael Kamoona \\ Assistant Professor \\ University of Baghdad \\ Baghdad-Iraq \\ g.kamoona@coeng.uobaghdad.edu.iq
}

\begin{abstract}
The construction sector consumes large amounts of energy during the lifetime of a building. This consumption starts with manufacturing and transferring building materials to the sites and demolishing this building after a long time of occupying it. The topic of energy conservation and finding the solution inside the building spaces become an important and urgent necessity. It is known that the roof is exposed to a high amount of thermal loads compared to other elements in a building envelope, so this needs some solutions and treatments to control the flow of the heat through them. These solutions and treatments may be achieved by using nanomaterials. Recently, nanomaterials have high properties, so that this made them good elements to the strategy of energy conservation in the architectural field. Accordingly, the research problem lay in "the lack of studies that deal with strategies to use nanomaterials in the roof of the building (especially the administrative building) in order to achieve energy conservation within its spaces". Then the research aims to: "Determine the efficient of nanomaterials in the roof to improving the thermal performance and achieving energy conservation in the indoor environment of the buildings in Iraq". This research's theoretical aspect has focused on using nanomaterial and their applications in roof systems. While in the experimental aspect, an administrative application to test a mass of identical administrates building in the design. In this research, simulation of the standard roof with nanomaterial, cool roof, and standard roof systems has been done using the Ecotect program. The results obtained in this research showed that the nanomaterial affected the thermal performance and achieved the indoor environment's quality by reducing to energy-consuming in the administrative building in the hot-dry climate of Iraq.
\end{abstract}

Keywords: Nanomaterials, energy conservation, indoor environment quality, building roof system.

\footnotetext{
*Corresponding author

Peer review under the responsibility of University of Baghdad.

https://doi.org/10.31026/j.eng.2021.02.09

2520-3339 () 2019 University of Baghdad. Production and hosting by Journal of Engineering.

This is an open access article under the CC BY4 license http://creativecommons.org/licenses/by/4.0/).

Article received: 9/10/2020
}

Article accepted: 10/11/2020

Article published:1/2/2021 


\title{
فاعلية المواد النانوية في سقف المبنى لتحقيق حفظ الطاقة في البيئة الداخلية للمبنى
}

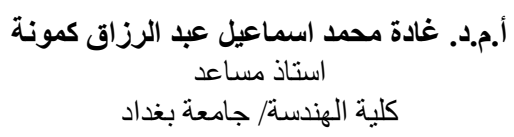

\begin{abstract}
الخلاصة
يستهلك قطاع البناء كميات كبيرة من الطاقة، بدءاً من مرحلة تصنيع مواد البناء البناء ونقلها الى مواقع الإنشاء، مروراً بمرحلتي

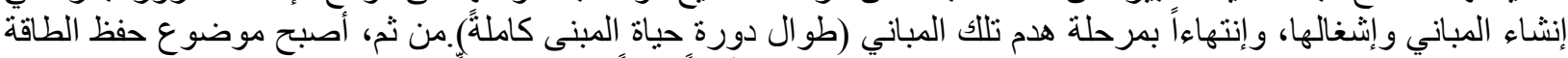

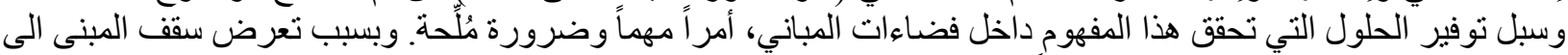

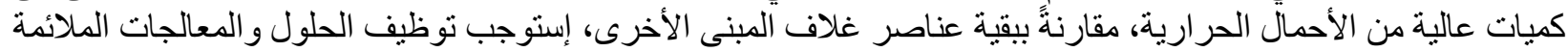

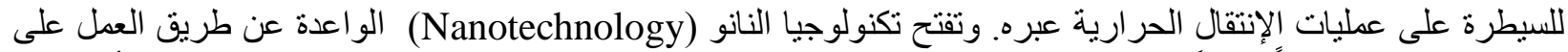

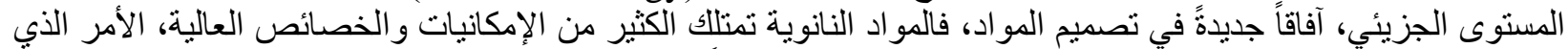

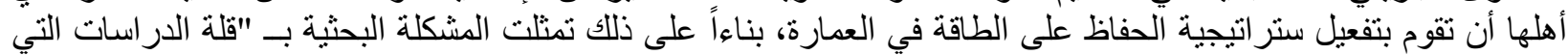

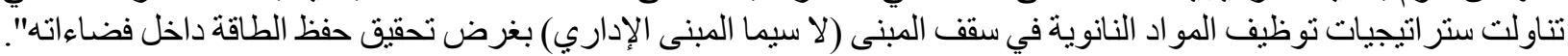

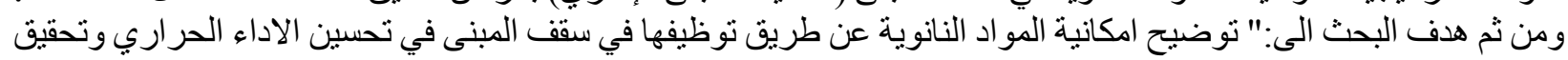

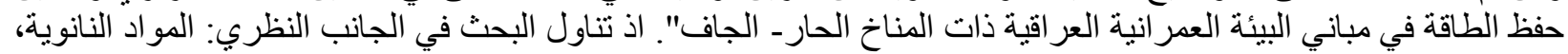

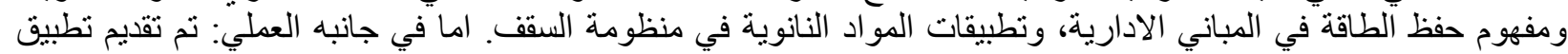

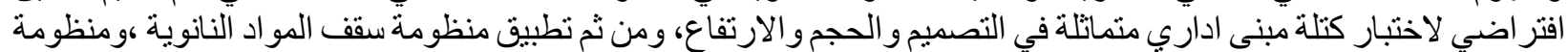

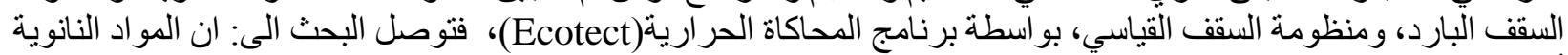

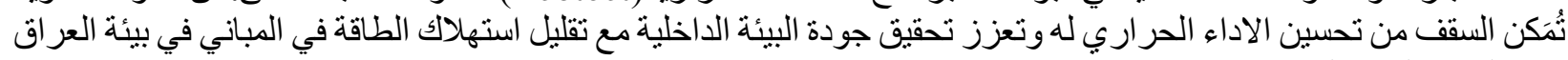

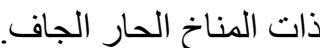
الكلمات الرئيسية: المواد النانوية، حفظ الطاقة، منظومة سقف المبنى، جودة البيئة الداخلية.
\end{abstract}

\section{INTRODUCTION}

Nanomaterials represent an essential breakthrough in the materials industry's technology; if there is a possibility to arise the properties of a particular material for achieving a specific goal, this represents a breakthrough in science and industry that enables the human being to develop his condition positively. Nanomaterials are considered a scientific application connected to the economy and represent a mean that cannot be underestimated in construction. Nanotechnology has been able to manufacture materials that enhance energy performance in building spaces and its high efficiency in insulation, durability, and others. The function of nanomaterials used in the roof of the administrative building is to reduce the thermal gain of the building roof. This will result in a comfortable indoor environment with thermal comfort, indoor air quality, as well as visual and voice comfort for the occupants enabling them to perform their tasks effectively and increase their productivity, and reduces illness, which represents the main aim of the research. In other words, it is aimed to explaining the possibility of applying nanomaterials upon the contemporary Iraqi administrative buildings by presenting a virtual application for choosing blocks for the design of identical buildings with distinctive nanomaterials roofs systems which are in coordination with the hot and dry climate of Baghdad for enriching the architecture experience in general and the administrative experience in particular.

\section{THE THEORETICAL ASPECT:}

\subsection{Nanomaterial}

Nanotechnology is considered a basic technology for fostering essential breakthroughs in vital areas such as health care, energy, the environment, and manufacturing. It allows industries to stay competitive, as nanoscience introduces an entirely new approach to research and development, which aims to control the structure of the material and its basic behavior at both atomic and 
molecular levels. The achievements that nanotechnology makes in building and construction are often of a sustainable nature that enhances the building's environmental performance (Casini, 2016).

Nanotechnology represents the processing, design, and manufacture at the molecular level. By employing these capabilities, sustainable buildings can be provided with extensive features that enhance energy conservation and improve building performance, environmental sensing, and sustainability. Nanomaterials are used to regulate temperature, heat-absorbing windows, insulation, smart nanotechnology for controlling light and heat, air purification coatings, and selfcleaning coatings (Kamoona, 2015).

Nanotechnology is defined as the application of scientific insights to control the components of materials and their use in the range of a nanoscale size (about one to 100 nanometers; one nanometer equals 10-9 meters), where special properties and phenomena related to size or structure may occur (Hessen Nanotech, 2008).

Nanotechnology has various definitions, but it mainly refers to the scientific ability to understand and deal with the matter at high microscopic ranges or nanoscale, for example, from 0.1 to 100 nanometers (Ayodeji, 2017). Nanomaterials can be defined as materials with at least one dimension (length, width, height), smaller than 100 Nanometers, which demonstrate physical, chemical, and biological properties that are entirely different from their normal-sized counterparts (Prof et al., 2015).

In the energy sector, nanotechnology can provide essential benefits across the entire material supply chain, from production to distribution (energy transfer and heat transfer), storage (batteries, supercapacitors, and PCMs using nanomaterials) and end use (thermal insulation, lighting, and appliances), including renewable energy development, hydrogen generation, fuel cells, and smart grids with nano sensors for smart and flexible grid management (Casini, 2016).

\subsubsection{Advantages of Nanomaterials}

Nanotechnology and its applications have advantages that encourage their use in energy consumption reduction and conservation. These applications represent a link between materials science and engineering towards enhancing the innovative capacity of the industry. The most important advantage in applying nanotechnology to traditional building materials is that they can be designed with desirable properties to modify its related functions, which will help achieve sustainable construction practice. Accordingly, the nanomaterials have been able to achieve the following advantages (Ayodeji, 2017) and (Atwa et al., 2018):

- Enhancing traditional building materials' function by improving the properties of the materials themselves or granting them multiple properties.

- Reducing energy consumption by using materials that enhance the building envelope's thermal performance leads to improving the quality of the indoor environment of the building and enhancing the occupants' thermal comfort.

- Nanomaterials provide the possibility of obtaining a comfortable indoor environment without the need for mechanical or electronic techniques such as the use of all kinds of nano-coating (self-cleaning coating, anti-fingerprint coating, anti-stain coating, anti-fog coating, antiwriting coating, anti-scratch coating, anti-reflective coating, UV protection, and air purification, and antibacterial coating).

- Increasing the indoor air quality (IAQ) in buildings by producing high-performance new generation materials with low emission.

- Nanomaterials Increase the durability of the building infrastructure, which reduces the consumption of resources and the consumed energy for maintenance and rehabilitation purposes. 
- Creating a new economy for new building materials and change the building into a knowledge-based economic activity.

- Improving health evaluation methods for the whole construction structure.

- Manufacturing of materials that have a long service life, which is reflected positively in economic terms.

- Some nanomaterials have a high recycling ability, which has a positive effect on reducing raw material consumption.

\subsubsection{Disadvantages of Nanomaterials:}

Although Nanomaterials possess a wide range of advantages, they include a set of imperfection that reflects the faults and weaknesses of the system, such as the following (Aithal and Aithal,

2016):

- Nanomaterials Life Cycle Assessment: The LCA methodology has been applied with difficulty in nanotechnology research, so the advantages and disadvantages according to its sustainability perspective are largely unknown.

- Nanoscale pollution: Despite the fast nanoscale industry and it's being moved forward in hundreds of areas, senior scientists cautioned against the formation of a new class or a whole system of non-degradable pollutants. Some studies have found in some nanomaterials used in the commercial field a possible risk up to toxicity to the environment and human health.

- High investment volume in research and development: Nanotechnology innovations require a tremendous amount of investment and research and high financial resources to conduct research and produce guaranteed results, but still produce a very limited result.

- Lack of knowledge among consumers: There is a knowledge contradiction between consumers in marketing and trading of nanotechnology and Nanomaterials, which led to their limited use.

\subsubsection{Nanomaterial standards}

Nanomaterials used in roofing systems include a set of standards. The most important of them are as follows (Harba and Merheg, 2017) and (Fouad, 2012):

- Energy efficiency should be in favor of Nanomaterials when comparing traditional materials and nanomaterials.

- Nanomaterials should have the ability to reduce heat gain through the building envelope in the summer and heat loss in winter, without the need for mechanical and electronic technologies to improve the indoor environment.

- Nanomaterials can reduce carbon emissions and volatile toxic substances in the environment.

- They could be of high durability and long service life with the possibility of recycling and antibacterial use (Papadaki et al., 2018).

\subsection{Nanotechnology and architecture}

In the architecture and construction industry, nanotechnology applications vary from the improvement of the traditional properties of concrete (as anticorrosive protection), improve materials and products such as paints, sealants, glass to make them waterproof and repellent to 
bacteria and other noxious biological agents to the betterment of thermal and pyro-resistant properties as Nano-compounds (Hernández-Moreno and Solache de la Torre, 2017).

In addition to titanium dioxide $\left(\mathrm{TiO}_{2}\right)$, nano oxide, alumina, silver, carbon nanotubes, nanofibers, quantum dots, nanoferous oxide, and zinc oxide, these are just some of the nanomaterials that have been produced to improve performance in the construction sector, which exist as materials incorporated into building matrices (such as cement) for mechanical strength, flexibility and decontamination or as a self-cleaning coating or stone protection or antibacterial use (Papadaki et al., 2018).

\subsection{Building roof system}

Roofing systems around the world have many materials and components that differ according to climatic factors, the availability of raw materials, and the construction systems commonly used within the geographical area. Usually, non-residential buildings' roofing is made of pre-cast concrete, pre-stressed concrete, corrugated metal (galvanized steel or aluminum), or concrete fibers that enhance the cast in site concrete or painted gypsum. While concrete decking increases a system's thermal mass, they provide little resistance to heat transfer across the roof (Jones, 2010).

Moreover, what enhances the importance of the roof performance and its ability to be used to improve the thermal performance of the building envelope is the time lag factor that the heat takes to move through the roof material from the outside surface to the inside. This will be a key indicator (initial criteria or standard) in choosing the roof construction's appropriate materials. However, choosing the appropriate materials for the roof does not mean eliminating the heat flow through it completely, so some treatments must be taken to construct the roof to reduce the running of heat energy through it to the building's indoor environment (Kamoona, 2009).

Overall, the design of building roofs affects changes in temperature and energy performance and the resistance of water and air quality. The roofs can support sustainable development and energy conservation, and consequently, the local climate (microclimate) in the surrounding of the building. Roofs also contribute to economic growth, environmental protection, and human well-being. Therefore, it is important to know the possibility of the roofs to support sustainable development and energy conservation through the following (Guzmán-sánchez et al., 2018):

- The roof must have an Albedo coefficient ${ }^{(1)}$, enhancing the building's roof's thermal performance.

- The possibility of thermal gain for the roof of the building and contribution to enhancing solar cells' performance.

- The ability of roof components to reduce the percentage of carbon emissions in the atmosphere, which means taking into account the durability of the material, and its ability to preserve its physical and mechanical properties throughout its life cycle such as interaction with oxidizing agents; resistance in acid or alkaline environments, and water absorption resistance.

- The possibility of roofs to reduce pollution and reduce temperature.

- The ability of roofs to conserve environmental diversity.

- The ability of the roofs to provide thermal and acoustic insulation.

\footnotetext{
(1) albedo : is determines how much sunlight will be absorbed and warm the surface compared to another surface that reflects most of the light and does not change temperature. so the Albedo is another name for reflectivity, (https://climate.ncsu.edu/edu/Albedo).
} 
- The life cycle cost of the building, where the roof life cycle must be evaluated and to improve environmentally friendly design solutions by taking into account the impact during the construction, operating and final disposal of the roof.

- The ability of the roofs to contribute to improving the aesthetic image.

\subsection{Concept of energy conservation in the building}

Globally, concern prevails concerning energy consumption in the built environment, in which buildings are the main contributor. This is reflected in the increase of gas emissions, which is considered as the reason for climate change and its associated effects. Most of the energy consumption in buildings is used to achieve and maintain the quality of the internal environment for buildings. A large amount of the energy used in buildings is to provide cooling, heating, and ventilation.

Energy Conservation is defined as "the wise use and conscious management of energy sources by using them for a specific purpose in an efficient manner or completely reducing its use", which implies the meaning of energy conservation (Kamoona, 2015).

Energy conservation means: "using energy only when it is needed and using it as much as possible for a function and not wasting any of it", which requires a conscious effort by the users of the energy to regularly ensure that there is no waste in it. And it also requires a lot of behavioral change in energy consumption(Jain, 2016).

Therefore, energy conservation is emphasized in the buildings sector, especially administrative buildings, as it is a concept that seeks to reduce energy consumption. And therefore, high efficiency by relying on renewable energies and reducing the use of fossil energy sources, and as a result contributing to securing energy supplies and reducing greenhouse gas emissions (GHG) (Carl and Haufe, 2018).

It is important that the building's primary goal is to make maximum use of passive systems to save and conserve energy to depend less on active systems that use energy significantly. Therefore, an efficient design strategy must be chosen to guarantee the occupants' comfort and achieve the principle of energy conservation, ease of operation, and maintenance (Smith, 2005).

The roofs carry out between $(50-70) \%$ of the total thermal loads applied to the envelope of the building, especially being the roof receives large amounts of solar radiation during daylight hours. The roofing's correct design is the main factor for improving thermal and energy performance to the indoor space of a building, compared to other building envelope elements. Taking to more energy conservation, these are the factor that must be considered carefully (Jones, 2010):

- Study climatic factors, especially solar radiation and temperature at the building site, to control thermal transfer across the roof.

- Employing solar photovoltaic panels or thermal solar panels and using them in the building roof to raise its energy efficiency is renewable energy.

- A correct design of the roof of the building to enable it to drain the rain water on it, to be kept for the purpose of recycling and using it for irrigation purposes later. 
- The use of materials that can be recycled and used on the roof to reduce or even eliminate the negative impacts on the building perimeter.

Energy consumption can be significantly reduced in buildings equipped with a sustainable roof, as it has the effect of reducing heat flow through the roof block, especially the roof using Nanomaterials, which improves the quality of the interior environment that reduces energy consumption.

The research has reached the procedural definition of energy conservation, as follows: the use of energy to achieve a specific goal, without failing to fully achieve that goal for reducing energy consumption, through efficient and wise use of available energy sources and focusing on the use of renewable energies. The primary goal of energy conservation lies in a considerate use of the energy sources, and this concept can be achieved through several strategies of design, operation, and guidance in the occupancy stage. And the last one is very important to be achieved especially it does not need additional financial costs.

\subsection{The importance of Nanomaterials in energy conservation}

The selection of building materials and methods for their implementation is important to reduce energy consumption, including the ability of building materials to gain or lose solar energy, and therefore reduce air conditioning loads, as the choice of low-energy materials (by mining, processing, manufacturing and transporting materials) will help reduce energy consumption. For example, aluminum has a very high embodied energy due to the large amount of electricity consumed to extract raw materials.

The impact of Nanomaterials in the energy field and the concept of energy conservation is enormous. It can achieve transformative changes in energy conservation and use by providing sustainable, clean, and efficient energy, and above all, a decarbonized energy system. Energy saving is achieved by the building materials industry, which includes technologies such as better insulation as nano-gel, solid lighting (LEDs) and (OLEDs), and nanoscale coatings of various kinds, as the whole building nanomaterials enhance energy consumption (Hernández-Moreno and Solache de la Torre, 2017).

As a result, nanomaterials reduce energy consumption when implemented and manufactured. Mostly, nanomaterials have a long life that reduces raw material consumption and reduces energy consumed in manufacturing, transporting, operating, and maintaining materials, then achieving the concept of energy conservation by employing nanomaterials in the construction sector. So Nanomaterials technologies can improve the building roof's thermal performance in a way that contributes to achieving energy conservation within its spaces and raising the quality of the indoor environment with high efficiency in use, Fig.1. 


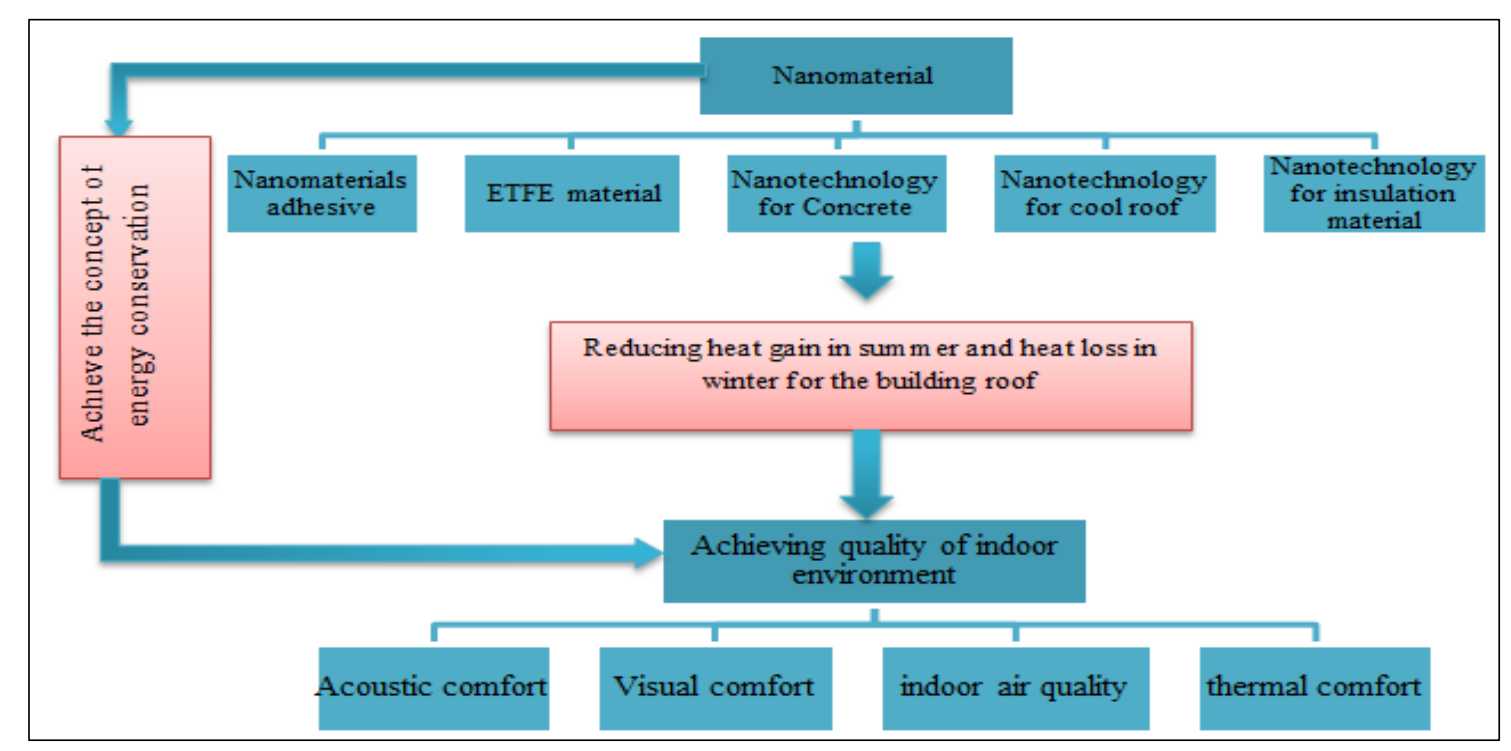

Figure 1.The diagram of the effect of using Nanomaterials on the roof of the building on achieving the concept of energy conservation within its spaces ( source: researchers).

\subsection{The effect of energy conservation on improving the indoor environment quality in the building}

The indoor environment quality is one of the most important requirements that the architectural designer aim to achieve. Because it has a significant impact on enhancing the health, safety, and well-being of occupants, regardless of gender, age, or space function, as it is an important factor with which the suitability of space is measured whether it is convenient for occupancy or not.

The indoor Environment Quality (IEQ) is considered according to "Building Ecology" as the representation of the efficient accommodation and comfort of the occupants of the interior spaces according to what is referred to as their total psychological and physical reactions to the architectural design factors. There are four main elements that make up the quality of the interior environment: thermal comfort, indoor air quality (ventilation), the level of lighting, and noise (Hernández-Moreno and Solache de la Torre, 2017).

The indoor environment quality is defined as an indication of the quality of the building's environment in relation to the health and well-being of the occupants of the interior spaces. IEQ is determined by many factors, including lighting, air quality, and humidity levels. Indoor environments are very complicated, and occupants may be exposed to a variety of pollutants (in the form of gases and particles) from office machines, cleaning products, building activities, carpets, furniture, perfumes, cigarette smoke, building materials that have been damaged moisture, growth of microbes (fungi, mold, bacteria), insects and external pollutants. These pollutants result from other factors such as temperature, relative humidity, ventilation levels, and how individuals respond to the internal environment (National Institute for Occupational Safety and Health, NIOSH, 2013).

The architectural designer and occupants have long been challenged about providing highquality indoor environments at a reasonable cost of energy, as current efforts focus on improving 
energy efficiency and the quality of the indoor environment at the same time. (Persily and Emmerich, 2012), And it reduces the possibility of occupants' illness, given that a person spends more than $90 \%$ of his life inside buildings in general. Hence, it is important to understand the internal environment and its parameters and act accordingly (Al et al., 2016). The quality of the indoor environment is essential on several levels, and as below:

Energy level: The quality of the indoor environment is an important feature of the buildings that seek to reduce energy consumption and achieve efficient use of it due to their direct impact in determining the amount of energy consumed, as researches in the field of sustainable building design and user well-being focused on energy performance, daylight, ventilation, and acoustics as well as occupant's feedback and reaction. As well as the well-being and comfort of the building occupant may interfere with the building's performance.

Environmental level: The World Health Organization issued a document stating that access to a healthy internal environment is a human right, which indicates the importance of achieving the quality of the internal environment, and building laws must pursue to achieve this (CedeñoLaurent et al., 2018). The use of the site's environmental aspects as a source of energy is less expensive than using devices such as natural ventilation and natural lighting. Numerous solutions seek to achieve a building with a sustainable internal environment, starting with green buildings, smart buildings, and interactive buildings (adaptive building), which has become a common topic in various academic discussions and research investigations and practical applications related to architecture and the construction industry (Ghaffarianhoseini et al., 2018).

Health Level: The quality of the indoor environment is an essential factor in the appearance of symptoms of Sick building syndrome (SBS), which is a group of health problems caused by the indoor environment in buildings such as an office building or residence, as a result of the closure of natural openings, and the use of new building materials that have not been adequately tested and certified, and the type of furniture and office equipment (printer, PC) as they all can contribute to SBS since they contribute to discomfort and affect the health aspect of occupants, which negatively affects the occupants' comfort and productivity (Al et al., 2016). This shift is associated with the commitment to design healthy environments that encourage productive workplaces that care for the health of their occupants and improve natural environments and ecosystems together, as these changes provide opportunities for securing healthier lifestyles as well as maintaining urban development, protecting environmental safety, promoting greater equality and supporting more flexible low-carbon places in the future (Ghaffarianhoseini et al., 2018).

\subsection{Performance of the roof supported by Nanomaterials to reduce energy consumption}

The role of nanomaterial to improve the thermal performance of the roof, it divided into five initial categories, such as the research classified as follows: 


\subsection{1: Applications of Nanomaterials in the thermal insulation materials}

The insulation is very important to improve the performance of the roof and reduce heat gain. Some thermal insulation materials were treated with nanotechnology to give them additional insulation properties and make them sustainable with advanced performance, as will be mentioned:

\subsubsection{1: Vacuum insulation panels (VIPs)}

The vacuum insulation panel (VIP) is a very effective thermal insulation system for buildings, the thickness of the panel between (2-44) $\mathrm{mm}$ and consists of a cover surrounding the filling material for the vacuum. The materials used in the cover are usually plastic chips (mostly aluminum foil) or stainless steel. The filling material takes the form of foam, or glass fiber powder, and it is usually porous and anti-pressure. Nanomaterials here were employed to improve these panel insulation performance, which is used as an insulating layer in buildings' roofs. Nanomaterials reduce heat gain and achieve efficient building energy use by reducing energy demand inside the building spaces (Casini, 2016) and (Mukhopadhyaya et al., 2014).

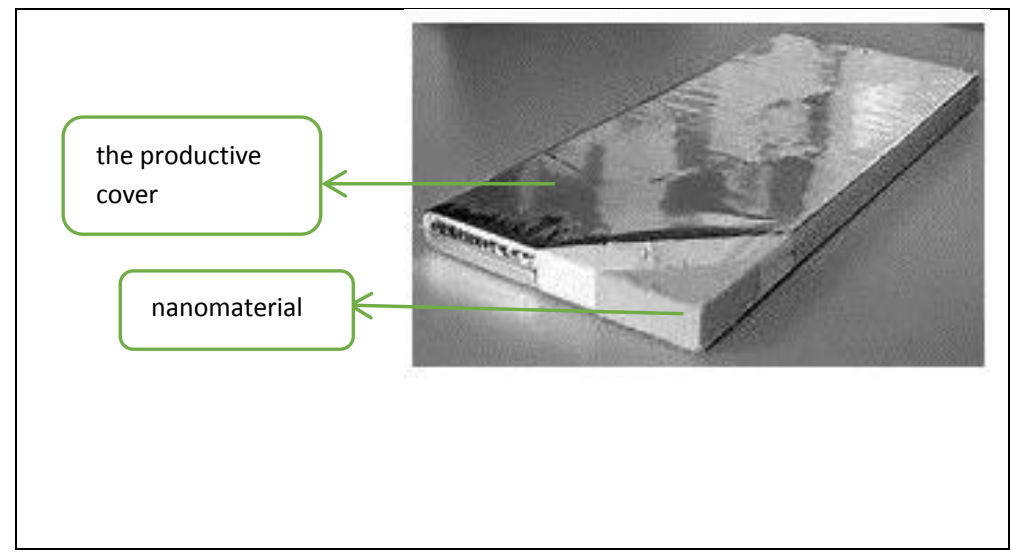

Figure 2. Vacuum insulation panels (VIPs) (source: https://www.asianproducts.com).

\subsubsection{2: Thermal Insulation Using Aerogel Material}

Aerogel is dried gels with very high porosity. Samuel Kistler discovered it in the early 1930s (Jelle et al., 2015), and it is considered the lightest solid at all $\left(60-80 \mathrm{~kg} / \mathrm{m}^{3}\right)$. It is used as an insulating material in windows, glass of roofs, or skylights roofing. It is used in thermal insulation for its porosity, which prevents heat transfer and at the same time makes it sensitive to moisture, so it is often applied in the form of fillings between the panels to resist moisture. Its transparency reaches $75 \%$. Among its advantages are its high ability for light transmission and low thermal conductivity (Berardi, 2017). Among the most important advantages of environmental aerogel (Casini, 2016).

- It is characterized by high environmental sustainability and is a non-toxic substance.

- Material with stable thermal performance, regardless of operating temperature, is used as insulation material for roofs, walls, and windows.

- It has High water resistance while maintaining high water vapor permeability.

- Aerogel has low flammability and fire-resistant. 
- It has Ultraviolet radiation-resistant.

- Aerogel is a material with high durability and high performance over time since it does not corrode and get punctured.

- Aerogel is easy to install thanks to its light material, easy adaptation, and storage.

Among the most important applications of aerogel at the roofs are the following (Berardi, 2017), (McEnaney et al., 2017), and (Aditya et al., 2017):

- Aerogel-based blankets Silica aerogels: They are panels made out of aerogel. They are shaped like fibers. These panels have small, unusual pores with exceptional physical, thermal, and acoustic properties (Fig.3).

- Aerogel as a finishing material (Aerogel-incorporating plasters): Aerogel is used in the form of a fixed and thermal insulating material to increase the building envelope's thermal performance, whether at the level of installation of roof finishing units or wall finishes. It can be easily used on flat or slop surfaces and allows applying a continuous thermal insulation layer by filling the gaps and joints. For the nature of the water repellent aerogel, the gypsum plaster avoids water absorption that can change the volumetric composition and the building envelope's final thermal performance, reducing energy consumption in the internal environment of the building's spaces (Fig.4).

- Translucent Aerogel Insulation Materials: The aerogel is considered very interesting for being a transparent or semi-transparent insulating material due to its combination of low thermal conductivity and high permeability of daylight and solar energy. And for this reason, insulated windows were manufactured extremely dependent on the granular Aerogel and the homogeneous Aerogel.

- Transparent Aerogel Insulation Materials: is to employ the transparent aerogel ability in a compact window and integrate it with the technology of vacuum glazing system by applying pressure ranging between (1-10 mbar). The dispersion becomes very visible if the aerogel window is exposed to direct solar radiation, making the current quality of transparent aerogel material more suitable for elements that operate in daylight as is often used in skylight roofing.

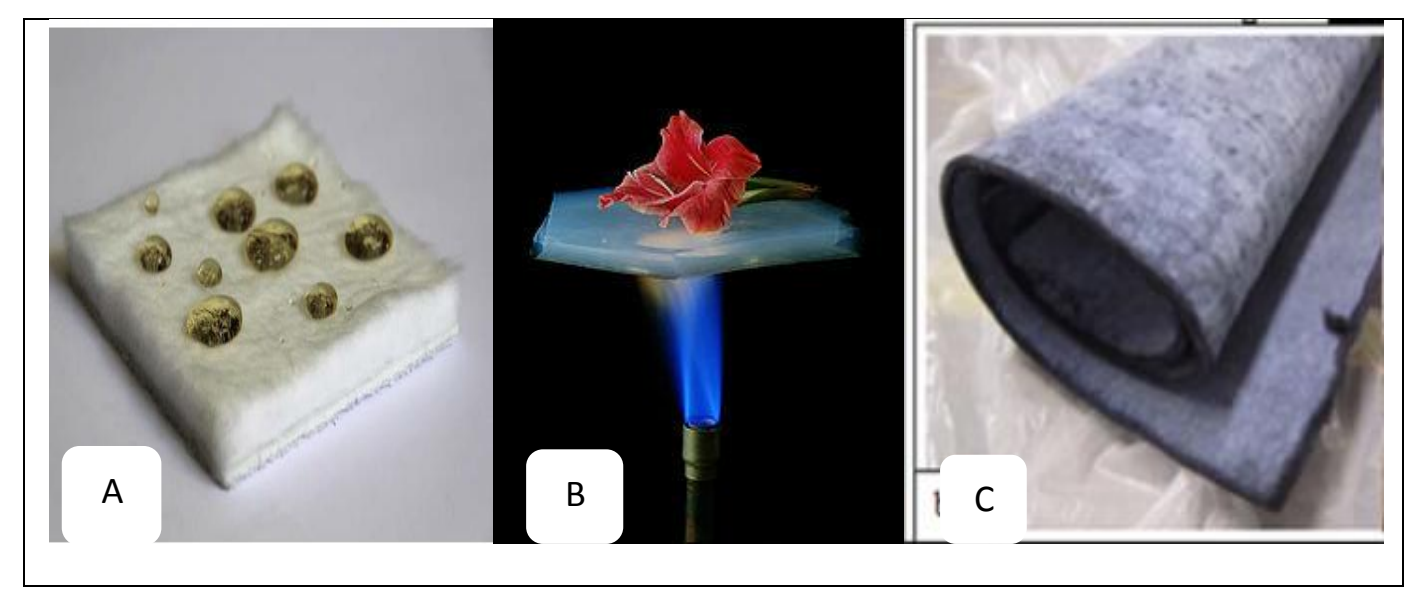

Figure 3.The Aerogel properties (A)Aerogel pillow, (B) Aerogel resistant to fire, (C)Aerogel resistant to water, (sources: https://en.wikipedia.org ) 


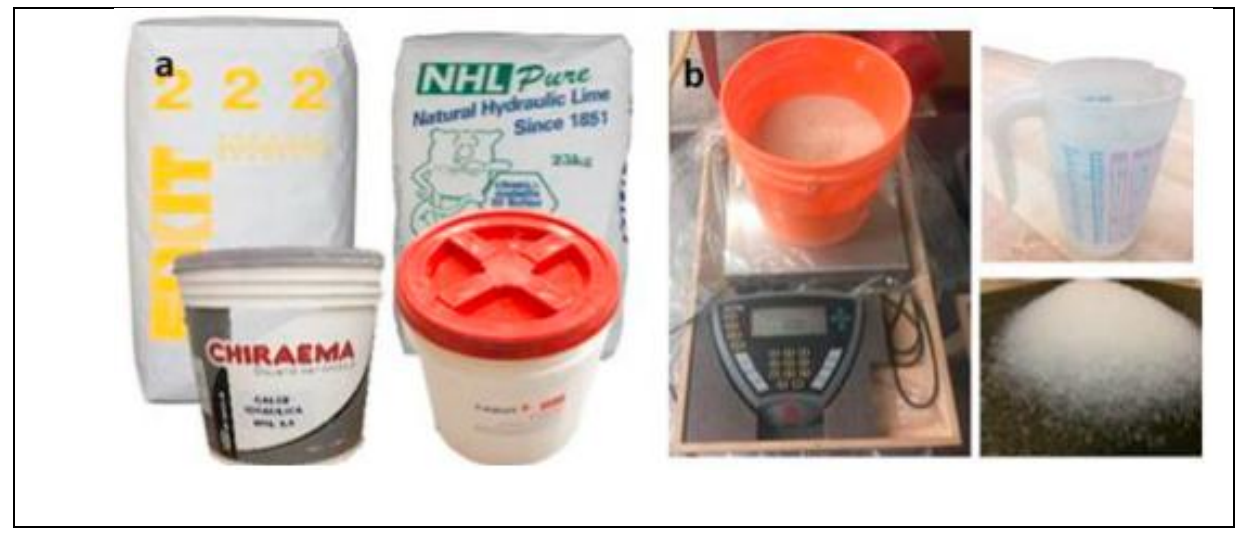

Figure 4. Aerogel as a finishing material (Aerogel-incorporating plaster).

\subsubsection{Nano Coating}

Modified cool roofs ${ }^{(2)}$ with nanomaterials are among the most important achievements of nanomaterials at the level of roofs. The most advanced nanotechnology products are used in cool roofs to reach high performance. Nanomaterials, in turn, reduce unwanted glow when be added to the coatings of cool roofs. This ensures high reflection and thermal emission levels in a wide range of color gradients, even dark colors (Hu and Yu, 2019). The effect of the conventional cool coating is by exploiting the upper layer that can reflect the visible element of the desired color, which has a high permeability to other wavelengths, and the mechanism of work in the case of a cool roof coated with high-reflective Nanomaterials in contrast to the infrared rate, towards the atmosphere (Figure2).

The transparent color layer containing pigments in the form of a tiny particle (A nanoparticle form) helps to invert the largest proportion of the sun's rays, as it performs a selective inverter (Casini, 2016). In general, the benefit of improving cool roofs with Nanomaterials is achieved through some applications, Table (1).

(2) cool roofs: is a powerful technology used for temperature control of buildings, which is prevents heat absorption by reflecting the sun's heat and then emitting its radiation back into the atmosphere. By doing this, cool roofs allow for a more comfortable and controlled indoor environment.(Green Building Alliance, 2019) 


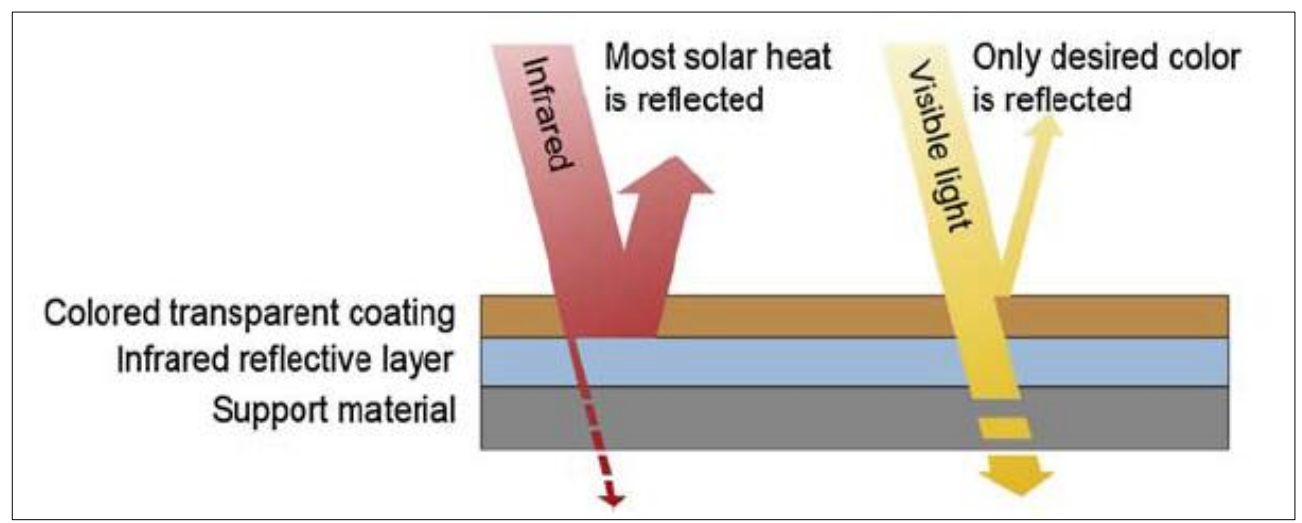

Figure 5. Application of cool Nanomaterial coatings (Casini, 2016).

Table 1. Applications of Nanomaterials on cool roofs.

\begin{tabular}{|c|c|}
\hline Applications by using nanomaterial & The Mechanism \\
\hline $\begin{array}{l}\text { - Radiative sky cooling: It is the process of } \\
\text { improving the cool roof and making it } \\
\text { not only affected by solar heating. It will } \\
\text { be rather cooler than the surrounding air } \\
\text { by removing heat from the roof and } \\
\text { pumping it into the sky. }\end{array}$ & $\begin{array}{l}\text { By applying a model called the sky window }{ }^{(3)} \\
\text { consisting of a square wooden structure wrapped } \\
\text { with aluminum foil. It is supplied with a glass } \\
\text { window coated with cool Nanomaterials, Fig. } \\
\text { (6). The role of this window is to radiate the } \\
\text { coming heat away without being moved inside } \\
\text { the building. The mechanism happens by creating } \\
\text { an air- hole around the window and heating it to } \\
\text { a minimum due to the resulting solar radiation, } \\
\text { then reducing the heat load of air inside the hole. } \\
\text { This will reduce the thermal transfer to the } \\
\text { building's interior and reduces air conditioning } \\
\text { costs by } 50 \% \text { during the summer. Yet, it increases } \\
\text { energy consumption noticeably for heating } \\
\text { during winter (Raman et al., 2014)(Casini, } \\
\text { 2016). }\end{array}$ \\
\hline $\begin{array}{l}\text { - Thermochromic materials: The } \\
\text { Nanothermic materials can reverse } \\
\text { optical properties in response to } \\
\text { environmental temperatures, such as } \\
\text { Titanium Dioxide }\left(\mathrm{TiO}_{2}\right) \text {, which can } \\
\text { reduce energy demand in building spaces } \\
\text { by adjusting the heat transfer across the } \\
\text { building envelope. }\end{array}$ & $\begin{array}{l}\text { Thermochromic materials reduce the unwanted } \\
\text { solar thermal gain during hot seasons and } \\
\text { increase solar thermal gain during cold seasons } \\
\text { while correcting the defect in the cool roof's work } \\
\text { in some cold climates in which the regular cool } \\
\text { roof does not help to reduce heating loads. } \\
\text { Thermochromic materials also reduce the }\end{array}$ \\
\hline
\end{tabular}

$\left.{ }^{3}\right)$ Sky window: It represents the time interval in which a specific set of wavelengths emitted by objects towards the sky is absorbed and is between $(8-13) \mathrm{mm}$ and the heat absorbed is free to reach space without being absorbed from the air or clouds, and is the main channel Through which the Earth loses the energy gained from the sun [1]. 


\begin{tabular}{|c|c|}
\hline & $\begin{array}{l}\text { thermally changing effect of urban heat islands } \\
\text { (UHI) and air pollution }(\mathbf{H u} \text { and } Y \mathbf{u}, \mathbf{2 0 1 9}) \text {. }\end{array}$ \\
\hline $\begin{array}{l}\text { - Cool roof coating with changing- phase } \\
\text { materials (PCM color coatings): These } \\
\text { materials are used as a coating layer for } \\
\text { the cool roof. They help reduce the } \\
\text { temperature of the roof without the need } \\
\text { for mechanical intervention. They also } \\
\text { help control the impact of urban heat } \\
\text { islands(), as they can reduce the } \\
\text { temperature of the cool roof surface } \\
\text { while maintaining a low temperature in } \\
\text { the building's indoor environment in the } \\
\text { summer season. }\end{array}$ & $\begin{array}{l}\text { PCM-coated roofs can securely store heat } \\
\text { while maintaining constant temperatures for a } \\
\text { roof with a late time flow. The colorful PCM } \\
\text { coatings can enhance thermal inertia and achieve } \\
\text { significant energy savings in buildings seeking to } \\
\text { achieve a thermally comfortable indoor } \\
\text { environment while keeping the roof surface } \\
\text { temperature low, and maintaining the indoor } \\
\text { temperature of the building higher than the cool } \\
\text { roof paint in the winter season (Chung and Park, } \\
\text { 2016). }\end{array}$ \\
\hline $\begin{array}{l}\text { - Lenticular cool roof: The lenticular } \\
\text { printing technology is a solution to the } \\
\text { white roof /dark roof's aesthetic issue. }\end{array}$ & $\begin{array}{l}\text { A cool roof uses a layer of semi-microscopic } \\
\text { lenses to direct light toward a background image, } \\
\text { similar to the effect of a 3D image. Hence, } \\
\text { perspective-colored variable roofs that appear in } \\
\text { white can be achieved if viewed from above, } \\
\text { interacting as a white surface that reflects Solar } \\
\text { radiation when the sun is high in the sky, with } \\
\text { another color (such as dark brown) or black or red } \\
\text { brick shown) when viewed from street level to } \\
\text { preserve the building's appearance (Gillis et al., } \\
\text { 2012), Fig. (7). }\end{array}$ \\
\hline
\end{tabular}

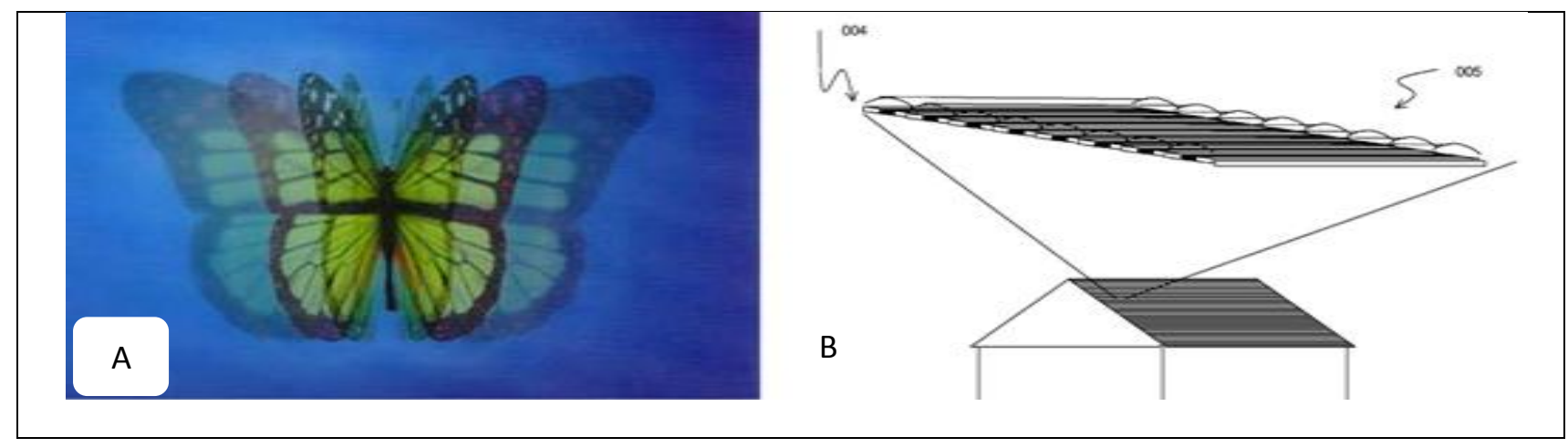

Figure 6. The Radiative sky window cooling device (A) applying the device to the roof of the building, (B) device details [31]. 


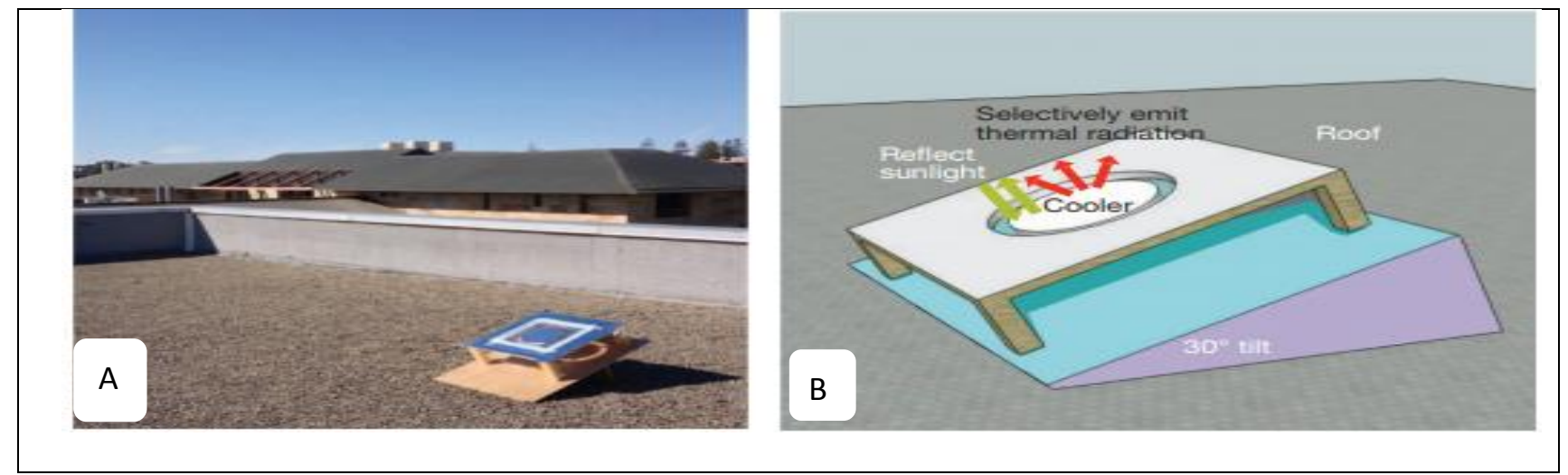

Figure 7.Mechanism of the cool roof with lens effect (A) lenticular printing, (B) Principle of a cold roof with lens effect (source: https://www.printshaq.com, https://www.analis.be).

\subsubsection{Applications of Nanotechnology on concrete}

Concrete with steel reinforcement represents the cornerstone in the sector of construction due to the properties they have. However, nanotechnology was applied to it to improve its performance Table (2).

Table 2. The types of concrete reinforced with Nanotechnology (Oke et al., 2017) and (Pradesh, 2012).

\begin{tabular}{|c|c|c|}
\hline $\begin{array}{l}\text { Concrete } \\
\text { Nanoparticles }\end{array}$ & Added nanoparticles & New or improved properties. \\
\hline 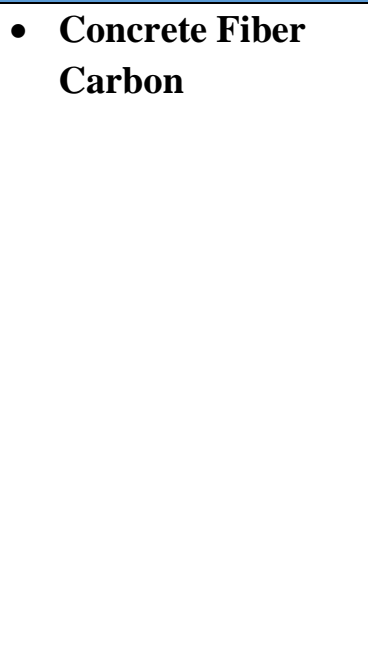 & Short carbon fiberglass & $\begin{array}{l}\text { - This type of concrete is characterized by } \\
\text { being heat-reflective, non-flammable, and } \\
\text { soundproof. } \\
\text { - It cannot be affected by water, moisture, or } \\
\text { sea salt. } \\
\text { - Light weight, easy for cleaning, } \\
\text { antibacterial, antifungal and anti-insects, } \\
\text { in addition to the possibility of coloring } \\
\text { them in different colors. } \\
\text { - It is the ideal choice for parametric designs } \\
\text { as it can be molded with high flexibility to } \\
\text { produce complex and regular shapes or } \\
\text { details. }\end{array}$ \\
\hline $\begin{array}{l}\text { - Light Transparent } \\
\text { Concrete }\end{array}$ & Optical fiber & $\begin{array}{l}\text { - Promotes the use of natural lighting as a } \\
\text { light source } \\
\text { - Reduces energy consumption for artificial } \\
\text { lighting. }\end{array}$ \\
\hline 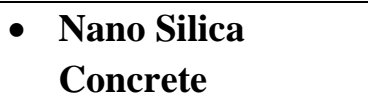 & Nano Silica & $\begin{array}{l}\text { - Controls the reactive decomposition of } \\
\text { concrete. }\end{array}$ \\
\hline
\end{tabular}




\begin{tabular}{|l|l|l|}
\hline & & $\begin{array}{l}\text { - Enhances the feature of water resistance. } \\
\text { Increases the compressive strength of } \\
\text { Portland cement. }\end{array}$ \\
\hline - Concrete $\left(\mathbf{T i O}_{2}\right)$ & $\begin{array}{l}\text { Titanium Dioxide } \\
\left(\mathrm{TiO}_{2}\right)\end{array}$ & $\begin{array}{l}\text { - Helps to reduce airborne pollutants. } \\
\text { - It has a high-performance reflective } \\
\text { surface. } \\
\text { - The surface is self-cleaning. }\end{array}$ \\
\hline $\begin{array}{l}\text { Concrete }(\mathbf{C N T}) \\
\text { or }(\mathbf{M C N T})\end{array}$ & $\begin{array}{l}\text { Carbon Nanotubes } \\
(\mathrm{CNT}) \text { or multi-walled } \\
\text { carbon tubes } \\
(\mathrm{MWCNTs})\end{array}$ & $\begin{array}{l}\text { - The bending capacity of concrete }(+8 \mathrm{n} / \\
\text { mm2). }\end{array}$ \\
\hline
\end{tabular}

\subsubsection{Ethylene tetrafluoroethylene(ETFE)}

It is a material used in architecture as inflated airbags to construct the envelope of buildings, roofs, or transparent facades of buildings, such as in ExCel Conference Center Building (Fig. 8). Generally, the properties which make this material a viable alternative to glass are the high transparency of solar radiation (90\%), light (its surface mass is $1 \%$ of the glass mass), and it also has a high mechanical resistance even at very high temperatures (higher) to $200^{\circ} \mathrm{C}$ ) (LeCuyer, 2008). It also can resist ultraviolet radiation and air pollution. And has a high ability of sound absorbency. ETFE also provides a high degree of thermal insulation and solar control. With a possibility of $100 \%$ recycling and a low level of embodied energy. It can cover areas with a large Span larger than traditional roofs (Liu et al., 2016).

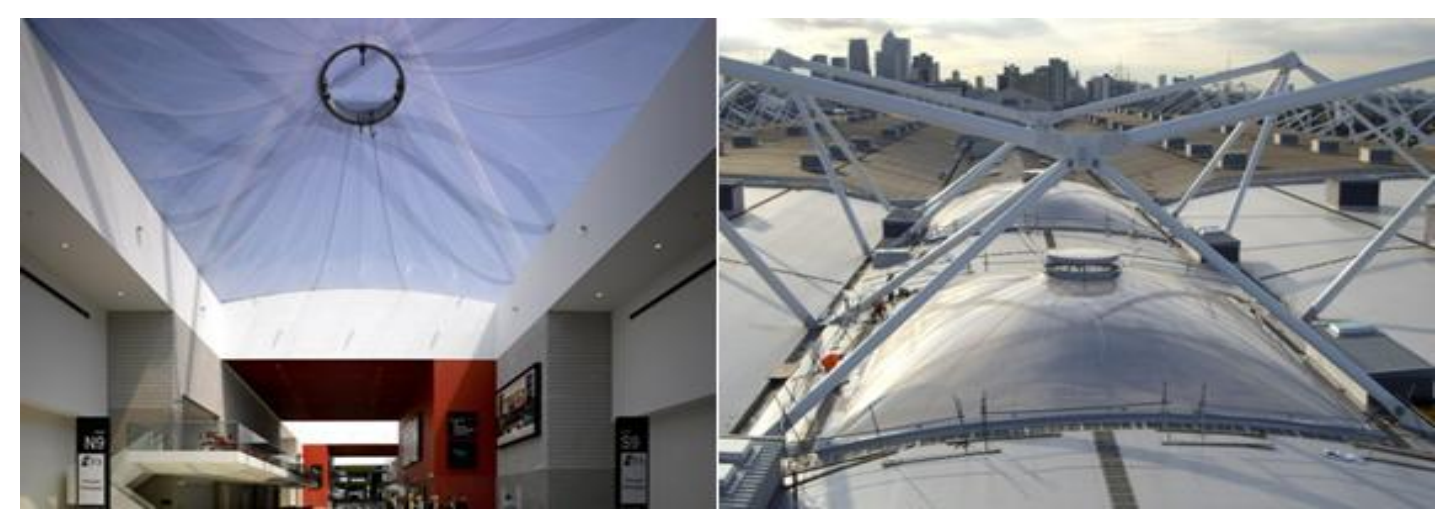

Figure 6. ExCel Conference Center roofing with ETFE (A) the interior view of the building, (B)the exterior view of the building (source: http://www.architen.com).

\subsubsection{Advanced Adhesive Nanomaterials}

Among the other Nanomaterials used in roof, applications are the adhesives Nanomaterials. Highperformance water-resistant glue has been applied to cool thin-film roofs and adherent roofs by 
utilizing polymers and integrating them with a synthesis protein. Therefore, reversible glue is made, which is the same glue used in dry and humid environments. It is also ten times more effective than traditional adhesives (Ahn et al., 2015).

\subsection{Potentials for applying Nanomaterials in the roof of buildings in hot, dry areas to achieve energy conservation}

Nanomaterials have a number of strategies that qualify them to achieve the concept of energy conservation in hot-dry climate (such as Iraq), which are as follows (Fouad, 2012) and (Hernández-Moreno and Solache de la Torre, 2017):

- Relative increase in the surface area: The nature of Nanomaterials comes with a larger surface area when compared to the same materials in the largest space. This makes them more chemically active as it affects their strength or electrical properties, which qualifies them to use as a motived material.

- Quantitative Effects: Nanomaterials are no longer subject to classical physics laws due to their small dimensions that are similar to atomic dimensions. Therefore, they are subject to quantum physics laws, which is reflected in their properties, as they possess the ability to change color and transparency, great rigidity, and great potential for conduction and insulation. So, it begins to control the behavior of the material in the nanoscale.

- Reducing the manufacturing cost of building materials: Nanotechnology shows significant savings during the manufacture of building-related products despite nanotechnology strategies focusing primarily on energy saving by reducing operating energy costs. Many other researches reported nanotechnologies to reduce production cost through more effective use of inputs.

- Nanomaterials' ability to adapt to the surrounding environment: This feature enhances the ability of Nanomaterials to improve the thermal performance required to achieve the quality of the indoor environment without the need for additional costs or mechanical intervention and increasing energy consumption for cooling or heating purposes.

\section{PRACTICAL ASPACT}

\subsection{Methodology}

The research hypothesis is that "roofs supported by nanomaterials can improve the thermal performance of indoor environment quality for building, which is represented the strategy of reducing energy consumption and achieving conception of energy conservation in buildings".

The experimental aspect of this study included calculating the thermal performance of the roof of a hypothetical medium-rise administrative building of (7) floors (in buildings with a height above the average, the effect of the roof is a few or neglected) by applying a thermal simulation using (Ecotect) program to the hypothetical administrative building with three various conditions of the roof including, they are as follows: The Standard roof; The Cool roof; and The Standard roof with the vacuum insulation panel (VIP), as well as installing the components of the structural systems for each of the walls, floors, openings, and windows for the three types of roofs. One of the most essential building data for thermal simulation as the following:

- Location: Baghdad - Iraq, latitude (33.20 north), and longitude (44.23 east), and the building is located at an angle $\left(-20^{\circ}\right)$ northeast.

- Real weather data for the city of Baghdad, which has a hot - dry climate in summer and cold in winter. 
- HVAC system: (mixed system).

- Workdays and times: 5 days a week from 6 a.m. - 6 p.m.

- Structural materials for the roofing system layers used in each case and their data: (material quality, thickness, thermal conductivity (K-value), density, thermal conductivity).

- Details of the hypothetical administrative building model: It is an administrative building with a height of (23 m) and consists of (7) floors with dimensions of (33.40 m width x $30 \mathrm{~m}$ length), Fig. (6) and (7). The virtual building also includes an internal central Atrium with an area of (195 m2). And covered with an Energy-Generating Glazing system called Photovoltaic glazing, in which the maximum energy of a single cell is (1000 watts) with peak-time efficiency of (265 watts). The dimensions of a single photovoltaic unit are $(1 \mathrm{~m} \times 1.7 \mathrm{~m})$ and provided (115) units of glass, sufficient to cover the Atrium of the building. It can provide (30457) watts of power. The quantity that can be used to reduce part of the energy consumption of fossil fuels for heating and cooling purposes or to operate office appliances and equipment. It is clean and renewable energy, especially when it promotes the achievement of energy conservation in the administrative building and adds sustainability to the administrative building in hot-dry climates.

After completing the necessary data and applying the two types of roofing systems (cool roof, traditional roof with vacuum insulation panel (VIP)) in addition to the traditional roof). The thermal analysis for all types of roofs (thermal gain in summer and heat loss in winter) has been done using a simulation program Thermoelectric (ECOTECT), with total comparison for all to determine the most efficient thermal performance roof system that achieves a comfortable internal environment, and enhances the concept of energy conservation through efficient use of energy. All calculations have been done during summer (from1st March to 31st October) and winter (from 1st November to 28th February). Table (3) illustrates the structural systems applied in the virtual administrative building's program and component.

Table 3. Component layers of the building envelope which were applied to a virtual administrative building within the simulation program (ECOTECT).

\begin{tabular}{|l|l|}
\hline $\begin{array}{l}\text { Elements of the } \\
\text { building envelope }\end{array}$ & The component layers for each element \\
\hline Standard roof & $\begin{array}{l}\text { Reinforce Concrete, Bitumen Impregnated Paper, two layers of } \\
\text { felt, Polystyrene, two layers of Sand and Soil (Avg. Props), and } \\
\text { Concrete screed. }\end{array}$ \\
\hline Cool roof & $\begin{array}{l}\text { Reinforce Concrete, Bitumen Impregnated Paper, two layers of } \\
\text { felt, Polystyrene, two layers of Sand and Soil, Concrete screed, } \\
\text { and PVC foil. }\end{array}$ \\
\hline $\begin{array}{l}\text { Standard roof with the } \\
\text { vacuum insulation } \\
\text { panel (VIP) }\end{array}$ & $\begin{array}{l}\text { Reinforce Concrete, Bitumen Impregnated Paper, two layers of } \\
\text { felt, vacuum insulation panel(VIP) (Nanomaterial), two layers of } \\
\text { Sand and Soil, and concrete screed. }\end{array}$ \\
\hline $\begin{array}{l}\text { Walls (for the three } \\
\text { types of roofs) }\end{array}$ & Gypsum, Brickwork, Concrete 1-4 Dry and Plasterboard. \\
\hline
\end{tabular}



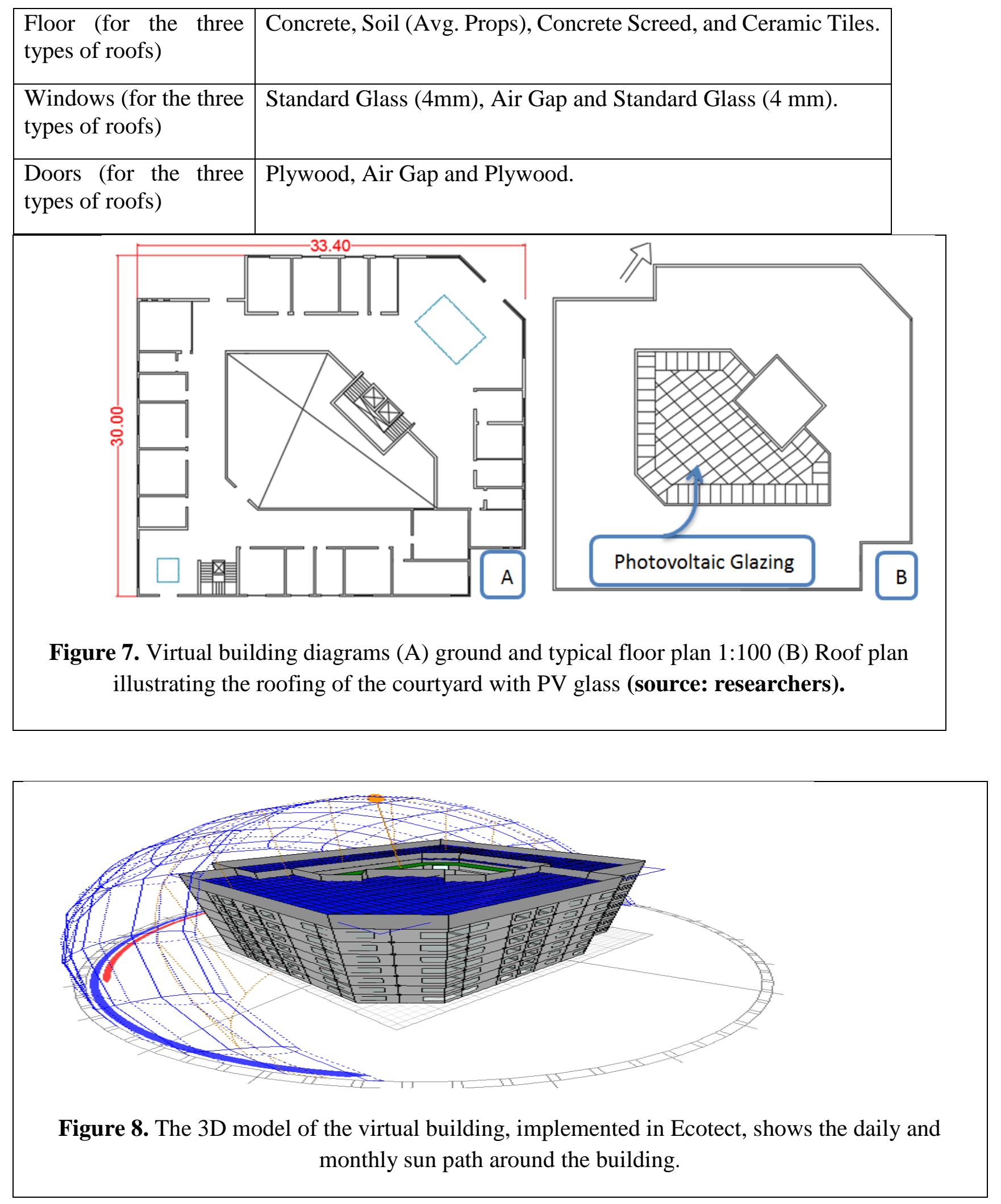


\subsection{Result and Discussion}

The thermal analysis by ECOTECT program of a hypothetical administrative building located in Baghdad within a hot and dry climate and test to three roofing systems' thermal performance in this research, Table (4). The results showed that there was a difference between the thermal performance of the three cases and the best performance has been achieved to the administrative building of standard roof with the vacuum insulation panel (VIP). The lowest heat gain has been achieved to it, which is considered the most important result during summer, which is the most extended season in Iraq. On the other hand, both the cool roof and standard roof with the vacuum insulation panel (VIP) had the lowest heat loss performance in the winter. All of this performance affected the indoor environment quality and comfort. It may be concluded the concept of energyconservation has been achieved by decreasing the demand for energy in cooling and heating efficiency.

Table 4. The thermal performance simulation results of a hypothetical administrative building with a standard roof, a cool roof, and a Standard roof with the vacuum insulation panel (VIP).

\begin{tabular}{|l|l|l|}
\hline Roof type & $\begin{array}{l}\text { The rate of heat } \\
\text { gain in summer }\end{array}$ & $\begin{array}{l}\text { The rate of heat loss in } \\
\text { winter }\end{array}$ \\
\hline Standard Roof & $66.00 \%$ & $63.80 \%$ \\
\hline Cool Roof & $61.80 \%$ & $54.20 \%$ \\
\hline $\begin{array}{l}\text { Standard roof with the vacuum } \\
\text { insulation panel (VIP) }\end{array}$ & $57.00 \%$ & $54.50 \%$ \\
\hline
\end{tabular}

\subsection{CONCLUSIONS:}

The research has reached the following conclusions:

1. The nanomaterials used in building construction reduce energy consumption in a clean and environmentally- friendly way. Nanotechnology is the handling of system atoms or molecules in the nanometer range without mechanical or electronic support.

2. Nanotechnology used in the field of Nanomaterials in the building envelope helps to consume energy within the building's spaces, thus achieving the concept of energy conservation in the building.

3. Nanotechnology technology provides wide-ranging capabilities that can be applied in building construction as it contributes to improving durability material properties.

4. The nanomaterials employed on the roof of the building improve the roof system's properties or add features that were not previously available within the system, or make the material multi-functional.

5. Nanomaterials enhance sustainability as they reduce the consumption of raw materials, reduce the energy consumed in material manufacture, improve the life cycle of some materials, and reduce carbon emissions and greenhouse gases. 
6. Nanomaterials help improve the building envelope's thermal performance in general (and the roof in particular), in which nanomaterials are used more efficiently compared to the traditional insulators.

7. Nanomaterials help improve cool roof performance by treating the concrete used (changing concrete properties) or producing high-performance adhesives for the cool roof.

8. Nanomaterials reduce heat gain in summer and increase heat gain in winter, especially when using a cold roof.

9. Nanomaterials improve material properties without the need for the production of entirely new materials.

10. The nanomaterials help the architect produce materials with properties that enhance the architectural design quality, such as adaptive packaging materials, sound-absorbing materials, varied and multitasking coating, and others.

11. Nanotechnology, which is based on the use of nanomaterials in the roof of the building (especially administrative buildings with high energy consumption) is an important means of achieving high quality in the indoor environment of the building as it seeks to improve thermal performance, visual comfort, and reduce or even eliminate the noise. As a result, the levels of comfort and quality of the indoor environment are improved.

\section{REFERENCES:}

- Aditya, L., Mahlia, T. M. I., Rismanchi, B., Ng, H. M., Hasan, M. H., Metselaar, H. S. C., Muraza, O., and Aditiya, H. B., 2017. A review on insulation materials for energy conservation in buildings. Renewable and Sustainable Energy Reviews, 73 (January), 1358. https://DOI.org/10.1016/j.rser.2017.02.034

- Al, Y., Arif, M., Katafygiotou, M., Mazroei, A., Kaushik, A., and Elsarrag, E., 2016. Impact of indoor environmental quality on occupant well-being and comfort : A review of the literature. International Journal of Sustainable Built Environment, 5(1), 7. https://DOI.org/10.1016/j.ijsbe.2016.03.006

- Atwa, M. S., Mohiuddin, I., and Al-Hajar, M. M., 2018. The effect of using nanotechnology and nanomaterials in the envelope of building on the indoor environment quality of buildings. Baheth, 1, 1-19. https://DOI.org/10.21625/baheth.v1i1.203.g96

- Berardi, U., 2017. The benefits of using aerogel-enhanced systems in building retrofits. Energy Procedia, 134, 626-635. https://DOI.org/10.1016/j.egypro.2017.09.576

- Carl, W., and Haufe, M., 2018. Adhesive composition and adhered roofing system prepared using the adhesive composition (Patent No. US 2018 / 0010021 A1). https://patents.google.com

- Casini, M., 2016. Advanced materials for architecture. In Smart Buildings (pp. 385,107,118,250-251.239). https://DOI.org/10.1016/b978-0-08-100635-1.00002-2

- Cedeño-Laurent, J. G., Williams, A., MacNaughton, P., Cao, X., Eitland, E., Spengler, J., and Allen, J., 2018. Building Evidence for Health: Green Buildings, Current Science, and Future Challenges. Annual Review of Public Health, 39(1), 291-308. https://DOI.org/10.1146/annurev-publhealth-031816-044420

- Chung, M. H., and Park, J. C., 2016. Development of PCM cool roof system to control urban heat island considering temperate climatic conditions. Energy and Buildings, 116(2016), 341-348. https://DOI.org/10.1016/j.enbuild.2015.12.056

- Fouad, F. F., 2012. NanoArchitecture and Sustainability. The University of Alexandria. 
- Ghaffarianhoseini, A., AlWaer, H., Omrany, H., Ghaffarianhoseini, A., Alalouch, C., Clements-Croome, D., and Tookey, J., 2018. Sick building syndrome: are we doing enough? Architectural Science Review, 61(3), 99-121. https://DOI.org/10.1080/00038628.2018.1461060

- Gillis, K. A., Grove, W., and Havey, D. K., 2012. STRUCTURAL MATERIALS WITH ANGLE DEPENDENT COLOR. 1(61), 1-138.

- Green Building Alliance., 2019. Cool Roofs. GREEN BUILDING METHODS ; COOL ROOFS. https://www.go-gba.org/resources/green-building-methods/cool-roofs/

- Guzmán-sánchez, S., Jato-espino, D., Lombillo, I., and Diaz-sarachaga, J. M., 2018. Assessment of the contributions of different flat roof types to achieving sustainable development. Building and Environment, 141(June), 128-183. https://DOI.org/10.1016/j.buildenv.2018.05.063

- Harba, O., and Merheg, L., 2017. Architecture the Light of Nanotechnology. Al-Baath University Journal, 39(18), 83-115.

- Hernández-Moreno, S., and Solache de la Torre, S. C., 2017. Nano-Technological Products in Architecture and Construction. Holos, 2, 34. https://DOI.org/10.15628/holos.2017.5497

- Hu, J., and Yu, X. B., 2019. Adaptive thermochromic roof system: Assessment of performance under different climates. Energy and Buildings, 192, 1-14. https://DOI.org/10.1016/j.enbuild.2019.02.040

- Jain, A., 2016. What is Energy Efficiency and how is it different from Energy Conservation? Bijli Bachao. https://www.bijlibachao.com/energy-efficiency-and-otherarticles/what-is-energy-efficiency-and-how-is-it-different-from-energy-conservation.html

- Jelle, B. P., Baetens, R., and Gustavsen, A., 2015. Aerogel Insulation for Building Applications. The Sol-Gel Handbook, 3-3, 1385-1412. https://DOI.org/10.1002/9783527670819.ch45

- Jones, J., 2010. Roofing materials for thermal performance and environmental integration of buildings. In M. R. Hall (Ed.), Materials for Energy Efficiency and Thermal Comfort in $\begin{array}{lllll}\text { Buildings (pp. 457,458, 459). } & \text { Elsevier. }\end{array}$ https://DOI.org/10.1533/9781845699277.2.455

- Kamoona, G. M. I., 2015. Green Architecture Systems in the Sustainable Environment Design"virtual Application for Greening the Presidency Building Of Baghdad University" (doctoral d). Architectural Engineering, Baghdad University.

- LeCuyer, A., 2008. ETFE: technology and design (Walter de). Walter de Gruyter.

- Liu, H., Li, B., Chen, Z., Zhou, T., and Zhang, Q., 2016. Solar radiation properties of common membrane roofs used in building structures. Materials and Design, 105, 268277. https://DOI.org/10.1016/j.matdes.2016.05.068

- McEnaney, K., Weinstein, L., Kraemer, D., Ghasemi, H., and Chen, G., 2017. Aerogelbased solar thermal receivers. Nano Energy, 40, 180-186. https://DOI.org/10.1016/j.nanoen.2017.08.006

- National Institute for Occupational Safety and Health(NIOSH), 2013. INDOOR ENVIRONMENTAL QUALITY. National Institute for Occupational Safety and Health. https://www.cdc.gov

- Oke, A., Aigbavboa, C., and Semenya, K., 2017. Review of the Application of Nanotechnology for Sustainable Construction Materials. In D. K. Kim, J. W. Hu, and J. K. Ahn (Eds.), Advances in Engineering Research (AER), volume 102364 Second International Conference on Mechanics, Materials and Structural Engineering (Vol. 102, 
Issue Icmmse, pp. 364-369). Atlantis Press. https://doi.org/https://DOI.org/10.2991/icmmse-17.2017.60

- Papadaki, D., Kiriakidis, G., and Tsoutsos, T., 2018. Applications of nanotechnology in construction industry. In Fundamentals of Nanoparticles. Elsevier Inc. https://DOI.org/10.1016/B978-0-323-51255-8/00011-2

- Persily, A. K., and Emmerich, S. J., 2012. Indoor air quality in sustainable, energy efficient $\begin{array}{llll}\text { buildings. HVAC } \quad \text { and } R \text { Research, } & \text { 18(1-2), } & 1-4,5,6 .\end{array}$ https://DOI.org/10.1080/10789669.2011.592106

- Pradesh, H., 2012. Application Of Nanotechnology In Building Materials. International Journal of Engineering Research and Applications, 2(October), 1077-1082.

- Raman, A. P., Anoma, M. A., Zhu, L., Rephaeli, E., and Fan, S., 2014. Passive radiative cooling below ambient air temperature under direct sunlight. Nature, 515(7528), 540544. https://DOI.org/10.1038/nature13883

- Smith, P. F., 2005. Architecture in a Climate of Change: A guide to sustainable design. Architectural Press An imprint of Elsevier. 